\title{
A Comparative Study on Teacher Talk of Australian and Chinese English Teachers in an Academic English Writing Course in Chinese EFL Classrooms
}

\author{
Julan Wang \\ SHU-UTS SILC Business School, Shanghai University, China
}

\begin{abstract}
Research on teacher talk has shown that many different teaching behaviors between native English speaking teachers and non-native English speaking teachers may result form their different English proficiency. This paper aims to examine the differences between Australian English teachers (AETs) and Chinese English teachers (CETs) in an Academic English Writing course in ELF classrooms in China in terms of language use, linguistic complexity, and linguistic variety. Two university teachers (one AET and one CET) were recorded and observed for two weeks in October of 2017 in SHU-UTS Business School of Shanghai University. Data were collected via classroom observation and analyzed by a qualitative research method. The findings revealed although there are some differences in language use, linguistic complexity and linguistic variety, both teachers are highly aware of the marking criteria for the writing task of the academic English writing course and emphasize their teacher talk quality input for their students. The results, therefore, can help teachers from Australian and Chinese cultures to continuously work on high quality teacher talk and facilitate the development of a specific language skill-academic English writing for English learners in EFL Chinese classrooms.
\end{abstract}

Index Terms - teacher talk, AETs, CETs, academic English writing, EFL classrooms

\section{INTRODUCTION}

In the recent two decades, many educational joint programs have been founded in many universities in China. SHU-UTS SILC Business School was founded back in 1994 and has already developed as a leading institute in these universities. One outstanding feature of all these programs is to conduct their courses in English, so intensive English courses are designed in the first year to help students develop proper English proficiency to prepare them well for their major studies. In order to alleviate the lack of qualified teachers, a surging number of English native speakers are employed to teach English in Chinese EFL classrooms. In relation to the issue who teaches English better in EFL classrooms, it is commonly assumed that native speaking teachers provide better input due to their English language proficiency. However, the quality of teacher talk also plays a significant role in students' foreign language learning. Studies that examined teacher talk of native speaking teachers and non-native speaking teachers not only are rare but also have mixed findings. Also, although an increasing number of Australians are teaching in many Sino-Australian educational joint programs, there is not a study to examine the differences of teacher talk given by Australian English teachers (AETs) and Chinese English teachers (CETs) in Chinese English language classrooms yet. The study aims to examine these differences and to explore whether language proficiency influences teacher talk as teacher's linguistic input and discuss the implications for teaching academic English writing.

\section{LITERATURE REVIEW}

Teacher's linguistic input or teacher talk is perhaps the most significant feature of a teacher. In language classrooms, its functions ranging from classroom management to input in the process of language acquisition cannot be stressed highly. Teacher talk for learners is generally recognized as a potentially valuable source of comprehensible input which is viewed as an essential part for language acquisition (Cullen, 1998). Researchers have discovered that native speakers' input to non-native students is modified in various ways, in both spoken and written mode (Ellis, 1985b; Chaudron, 1998). Hadley (2001) pointed out that good teacher talk is an interactional input with modifications in classrooms and aims to facilitate learner's comprehension in the language acquisition process. Many teacher talk studies have examined its forms, grammatical aspects and IRF (Initiation-Response-Feedback) exchange (Breidbach, Daniela and Andrea, 2011; Chadwick, 2012; Warford, 2007; Nakaruma, 2008; Hale, 2011), but how teachers should use this awareness raising to facilitate English language learners' acquiring specific language skills is not widely researched yet. Moreover, because most teacher talk studies focus on discoursal and interactional features, its instructional and pedagogic effects on teaching English writing, especially academic English writing, is not well investigated (Kiasi and Hemmanti, 2014). 
Hall (2011) argues that teacher talk should be discussed for the sake of pedagogy and negotiated meaning in interaction.

In terms of teacher talk in writing, because of the complexity of writing skills, English learners' oral participation can be reduced. Therefore, teacher talk's quality is more important than its quantity if teachers aim to provide an invaluable comprehensible input for their learners (Culleen, 1998). Additionally, the importance of teacher talk in an academic English writing course is not just confined to the commonly discussed IRF or a quantitative view of teacher talk time (TTT), but its linguistic complexity and appropriateness to the content are more significant. Ellis (2003) argues that teacher talk should reflect a clear thematic focus in an EFL course and should be adjusted to the different levels of students' English proficiency. In an academic English writing class, because of different language proficiency between native English speaking teachers and non-native English speaking teachers, how they skillfully adjust their language in terms of linguistic complexity and linguistic variety is the primary purpose of the current study.

\section{RESEARCH DESIGN}

\section{A. Research Questions}

The research questions particularly focus on the use of English by AETs and CETs in an academic English writing course. The theme of the academic writing course is global issues with the focus on global water scarcity. In the course, there are two weeks specifically designed for writing assignment task which includes the analysis of the task itself, brainstorming ideas for the task, finding supporting evidence for the task, and outlining the task.

The study aims to answer the following questions: 1) What types and amounts of language use do AETs and CETs provide respectively in EFL classroom? 2) In terms of linguistic complexity, what are the differences between AETs and CETs in terms of mean length of utterance, polysyllabic words and difficult words? 3) In terms of linguistic variety, whatB. types and amounts of self-repetition are used by AETs and CETs in EFL classroom?

\section{B. Research Methods and Participants}

The study is basically of a qualitative research design by carrying out classroom observations of how one AET and one CET provided their linguistic input and by audio recording and field note taking of the two teachers' speech and classroom situation.

The background information of the two participating teachers is shown in table 1.

TABLE I.

BACKGROUND INFORMATION OF PARTICIPANTS

\begin{tabular}{|c|c|c|}
\hline \multicolumn{3}{|c|}{ BACKGROUND INFORMATION OF PARTICIPANTS } \\
\hline & AET & CET \\
\hline Class level & Freshman and sophomore & Freshman and sophomore \\
\hline Education & $\begin{array}{l}\text { Bachelor degree } \\
\text { (CELTA certificate) }\end{array}$ & $\begin{array}{l}\text { Master degree } \\
\text { (TESOL certificate) }\end{array}$ \\
\hline Teaching experience & Nearly 10 years & Almost 15 years \\
\hline Number of students & 45 (23 freshmen and 22 sophomores) & 44 (21 freshmen and 23 sophomores) \\
\hline
\end{tabular}

The reason for selecting 1 class freshmen and 1 class sophomore for each teacher is that some sophomores failed the course last time or they did not take the course in the first year because they are transferred students from other universities and they need to take the course to meet the English credit requirement of SHU-UTS SILC School. These four classes' students English proficiency level is quite similar because they took the placement test arranged by the school at the beginning of the term.

\section{Data Collection}

To collect as much and clear data as possible, the researcher set an audio recorder in the nearest place to the teacher. Each class period lasted 45 minutes and was observed carefully. Each teacher was observed and recorded for two weeks when they were covering the same unit in these two weeks. Each class was observed and recorded four times for four classes. In total, 16 class periods were observed and recorded. The recording was transcribed verbatim, and double checks with the two teacher participants were made as well in order to achieve accuracy. In addition, notes made on the on-spot observations were used to compare the recording.

\section{Data Analysis and Findings}

The data collected from two teachers were analyzed from two perspectives: form analysis and function analysis. For the form analysis, three characteristics were measured: language type, polysyllabic words and difficult words. For the function analysis, self-repetition of teacher talk was analyzed.

\section{E. Form Analysis}

In this study, form analysis aimed to answer the first two research questions: types and amounts of teacher talk (i.e. the ratio of L1/L2 use) and language complexity which comprises three indicators: mean length of utterance, polysyllabic words and difficulty words. 
The Study adapted Duff and Polio's (1990) method to quantify the ratio of L1/L2 use and each coded utterance produced by teachers was classified in this study as one of the followings: L1: The utterance is completely in Chinese. L1c: The utterance is in Chinese with one word or phrase in English. Mix: The utterance is approximately an equal mixture of Chinese and English. L2c: The utterance is in English with one word or phrase in Chinese. L2: The teacher's utterance is completely in English. The result was shown in table 2: the ratio of L1 and L2 use (\%)

TABLE II.

THE RATIO OF L1 AND L2 USE (\%)

\begin{tabular}{|c|c|c|c|c|c|c|c|c|c|c|c|c|c|c|}
\hline \multirow[t]{2}{*}{ Class } & \multicolumn{2}{|c|}{ AET (freshman class) } & \multicolumn{2}{|c|}{ AET (sophomore class) } & \multicolumn{5}{|c|}{ CET (freshman class) } & \multicolumn{5}{|c|}{ CET (sophomore class) } \\
\hline & L1 & $\mathrm{L} 2$ & L1 & L2 & L1 & L1c & Mix & L2c & $\mathrm{L} 2$ & L1 & L1c & Mix & L2c & L2 \\
\hline $1^{\text {st }}$ class & 0 & 100 & 0 & 100 & 0 & 3.6 & 0 & 6.8 & 89.6 & 0 & 5.2 & 0 & 4.2 & 90.6 \\
\hline $2^{\text {nd }}$ class & 0 & 100 & 0 & 100 & 0 & 4.2 & 0 & 3.6 & 92.2 & 0 & 2.6 & 0 & 4.3 & 93.1 \\
\hline $3^{\text {rd }}$ class & 0 & 100 & 0 & 100 & 0 & 5.9 & 0 & 6.2 & 87.9 & 0 & 4.7 & 0 & 5.6 & 89.7 \\
\hline $4^{\text {th }}$ class & 0 & 100 & 0 & 100 & 0 & 4.7 & 0 & 3.4 & 91.9 & 0 & 5.8 & 0 & 10.6 & 83.6 \\
\hline Average use & 0 & 100 & 0 & 100 & 0 & 4.6 & 0 & 5 & 90.4 & 0 & 4.6 & 0 & 6.2 & 89.3 \\
\hline
\end{tabular}

From table 2, it was found that the Australian English teacher used 100\% English in both freshman and sophomore classes, and the Chinese English teacher used both English and Chinese to conduct their teaching. However, the percentages of English used by the CET either in freshman or in sophomore classes were over $85 \%$ and no single utterance was completely in L1. A more close analysis of their recordings suggested that the CET used Chinese to translate new words, clarify some instructions, summarize main points and assign homework at the end of class.

According to Krashen (2004), one important thing in foreign language classroom is to provide learners enough target language input and exposure so that they can make progress by acquiring some authentic comprehensible input. Levine (2003) also pointed out that reducing L2 input to comfort students learning may not be a good way for non-native speaking teachers to relieve their anxiety in classroom. Instead, making L2 input more comprehensible either by verbal modifications or nonverbal cues would be a better solution.

On the other hand, researchers pointed out that L1 helps when it is used to provide background information at the beginning level and used separately from L2. Nevertheless, L1 may hinder learning when it is used to translate and learners have no change to attend to the L2 input (Krashen, 2004). In other words, while there is a role for L1 in the foreign language classroom, L2 still would be the major medium language. According to Tang (2002), 5 percent to 30 percent of L2 might be the best acceptable amount for learners. Therefore, although the amount of L1 used in class by the CET was acceptable, she needs to modify her strategies of explaining new words rather than by translating. Also, it is necessary for the Chinese English teacher to maximize L2 use in classroom. This improvement of target language can also meet the requirement of English only in EFL classrooms in the school. Additional, this change to use English only can motivate students to use English for discussions even when they encounter some challenges in their brainstorming activities.

\section{G. Language Complexity}

In this study, MLU (mean length of utterance), polysyllabic (three or more syllables) and difficult words are three indicators to assess language complexity of English was used. While MLU was used as a measure of sentence level complexity, polysyllabic and difficult words worked for vocabulary level. The results of complexity analysis were presented in table 3 (mean length of utterance), table 4 (polysyllabic words) and table 5 (difficult words), respectively.

1. Mean length of utterance

TABLE III.

MLU (MEAN LENGTH OF UTTERANCE)

\begin{tabular}{|l|l|l|l|l|}
\hline MLU & AET (freshman class) & $\begin{array}{l}\text { AET (sophomore } \\
\text { class) }\end{array}$ & CET (freshman class) & $\begin{array}{l}\text { CET } \\
\text { class) }\end{array}$ \\
\hline $1^{\text {st }}$ class & 8.54 & 8.49 & 6.74 & 7.93 \\
\hline $2^{\text {nd }}$ class & 7.59 & 8.65 & 6.96 & 8.03 \\
\hline $3^{\text {rd }}$ class & 8.23 & 8.72 & 7.25 & 7.48 \\
\hline $4^{\text {th }}$ class & 8.46 & 8.57 & 7.59 & 7.83 \\
\hline average & 8.205 & 8.6075 & 7.0675 & 7.8175 \\
\hline
\end{tabular}

As table 3 showed, the average MLU of CET for freshman and sophomore classes was 7.0675 and 7.8175 respectively, which was shorter than that of AET for freshman class (8.205) and AET for sophomore class (8.6075). Also, it was clear that for both AET and CET, MLU for freshmen was a bit lower than that for sophomores. This result was in accordance with Milk's findings (1985): MLU of the native speaking teacher was shorter to beginners than to advanced students. Even though the two sophomore classes did a placement test to be sorted out to be in the similar English proficiency level of the two freshmen classes, the two teacher participants may assume that second year students have one more year experience of learning English in universities, thus a seemingly higher language proficiency. Thus, in teaching practice, they uttered comparatively longer sentences in their talk when they are with sophomores. While English proficiency could be the reason for the CET producing shorter MLU, the use of Chinese in class may cause the CET to produce shorter MLU. 
2. Polysyllabic words

Data calculation of polysyllabic was analyzed by using computer software PREP Program. According to PREP Program, the average words of three or more syllables of each teacher discourse in the class were: 187.5, 206.25, 187.75, and 196.5.Table 4 specifically showed the result for each class in four respective class periods.

TABLE IV.

NUMBER OF POLYSYLLABIC WORDS

\begin{tabular}{|c|c|c|c|c|}
\hline $\begin{array}{c}\text { Number of } \\
\text { polysyllabic words }\end{array}$ & AET (freshman class) & $\begin{array}{c}\text { AET (sophomore } \\
\text { class) }\end{array}$ & CET (freshman class) & $\begin{array}{c}\text { CET (sophomore } \\
\text { class) }\end{array}$ \\
\hline $1^{\text {st }}$ class & 175 & 259 & 162 & 207 \\
\hline $2^{\text {nd }}$ class & 188 & 232 & 197 & 216 \\
\hline $3^{\text {rd }}$ class & 203 & 196 & 207 & 184 \\
\hline $4^{\text {th }}$ class & 184 & 138 & 185 & 179 \\
\hline average & 187.5 & 206.25 & 187.75 & 196.5 \\
\hline
\end{tabular}

This table showed that there were no great differences between the AET and the CET. Also, both of them used a high level of polysyllabic words in their teaching. This indicated that teachers increased significantly the use of polysyllabic words when compared with learners with lower-proficiency in English. The result also corresponded with the requirement of marking criteria for vocabulary for the writing task. In the marking criteria for the vocabulary, it was stated that a skillful use of less common words and academic word list (AWL) is required to get a highly distinguished mark. Since many of lesson common words and the academic word list are polysyllabic, teachers are setting themselves as good examples to their students in their talk in classes.

3. Difficult words

The other way of measuring lexically was the numbers of difficult words and the New Dale-Chall Formula was used in this study to evaluate difficult words. The New Dale-Chall Formula is an accurate readability formula because it is based on the use of familiar words, rather than syllable or letter counts. The calculation results of the number of difficult words were presented in table 5 as follows:

TABLE V.

NUMBER OF DIFFICULT WORDS

\begin{tabular}{|c|c|c|c|c|}
\hline $\begin{array}{c}\text { Number of difficult } \\
\text { words }\end{array}$ & AET (freshman class) & $\begin{array}{c}\text { AET (sophomore } \\
\text { class) }\end{array}$ & CET (freshman class) & $\begin{array}{c}\text { CET (sophomore } \\
\text { class) }\end{array}$ \\
\hline $1^{\text {st }}$ class & 175 & 189 & 145 & 176 \\
\hline $2^{\text {nd }}$ class & 162 & 204 & 159 & 209 \\
\hline $3^{\text {rd }}$ class & 148 & 184 & 186 & 183 \\
\hline $4^{\text {th }}$ class & 168 & 179 & 158 & 191 \\
\hline average & 163.25 & 189 & 162 & 189.75 \\
\hline
\end{tabular}

Table 5 showed that both the AET and the CET used more difficult words when teaching sophomores than teaching freshmen. This seems to imply that the more the use of difficult words, the higher the linguistic proficiency of learners teachers assume. Generally speaking, there was not much difference between AET and CET's difficult words, 163.25 for freshman class by the AET, 162 for freshman class by the CET, 189 for sophomore class by the AET, and 189.75 for sophomore class by CET respectively.

In summary, although the CET tended to offer shorter MLU in both freshman and sophomore classes, she actually used approximately same number of polysyllabic and difficult words as those used by the AET. That is, in terms of linguistic complexity, it seemed hard to draw a conclusion who, either the AET or the CET, provided more simple input. Although the AET's higher linguistic proficiency can make him produce longer utterances than his Chinese counterpart, good understanding of the lessons aims and marking criteria of the writing task make her not lag behind in polysyllabic and difficult words. In addition to being very familiar with the task requirement and marking criteria, the two teachers were both aware that all the classes plan to take IELTS (international English language testing system) in this coming summer. In IELTS, lexical resources are one of the criteria and this was well understood both by the AET and the CET when they did their lesson plans. As a result, in the teaching practice, both teachers emphasized this point.

\section{H. Function Analysis}

Self-repetition was defined as any utterances that repeat or paraphrase a preceding utterance, which can be treated as an index that reflects language variety. According to Urano (1999), there are three types of self-repetition: exact-repetition, expansion and paraphrase. Table 6 and 7 showed the results of amounts of self-repetition. 
TABLE VI.

The TOtal PERcentage Of SELF-RePetition OF All TeACHER TAlK

\begin{tabular}{|c|c|c|c|c|}
\hline $\begin{array}{ll}\text { results } & \text { of } \\
\text { self-repetition } & \\
\text { (total percentage) } & \end{array}$ & AET (freshman class) & $\begin{array}{l}\text { AET } \quad \text { (sophomore } \\
\text { class) }\end{array}$ & CET (freshman class) & $\begin{array}{l}\text { CET } \quad \text { (sophomore } \\
\text { class) }\end{array}$ \\
\hline $1^{\text {st }}$ class & $16.81 \%$ & $17.20 \%$ & $16.47 \%$ & $18.94 \%$ \\
\hline $2^{\text {nd }}$ class & $14.35 \%$ & $18.56 \%$ & $19.58 \%$ & $20.12 \%$ \\
\hline $3^{\text {rd }}$ class & $12.10 \&$ & $16.43 \%$ & $20.15 \%$ & $19.54 \%$ \\
\hline $4^{\text {th }}$ class & $15.73 \%$ & $13.41 \%$ & $18.86 \%$ & $22.72 \%$ \\
\hline average & $14.75 \%$ & $16.40 \%$ & $18.77 \%$ & $20.33 \%$ \\
\hline
\end{tabular}

TABLE VII.

PERCENTAGES Of EXACT REPETITION, EXPANSION, AND PARAPHRASE OUT OF THE TOTAL REPETITION

\begin{tabular}{|c|c|c|c|c|}
\hline $\begin{array}{l}\text { percentages } \\
\text { self-repetition }\end{array}$ & AET (freshman class) & $\begin{array}{l}\text { AET } \quad \text { (sophomore } \\
\text { class) }\end{array}$ & CET (freshman class) & $\begin{array}{l}\text { CET } \\
\text { class) }\end{array}$ \\
\hline $\begin{array}{l}1^{\text {st }} \text { class } \\
\text { exact repetition: } \\
\text { expansion: } \\
\text { paraphrase: }\end{array}$ & $\begin{array}{l}17.42 \% \\
54.93 \% \\
27.65 \%\end{array}$ & $\begin{array}{l}21.52 \% \\
67.36 \% \\
11.12 \%\end{array}$ & $\begin{array}{l}22.59 \% \\
68.32 \& \\
9.09 \%\end{array}$ & $\begin{array}{l}19.53 \% \\
70.27 \% \\
10.2 \%\end{array}$ \\
\hline $\begin{array}{l}2^{\text {nd }} \text { class } \\
\text { exact repetition: } \\
\text { expansion: } \\
\text { paraphrase: }\end{array}$ & $\begin{array}{l}20.20 \% \\
59.38 \% \\
20.42 \%\end{array}$ & $\begin{array}{l}24.53 \% \\
56.74 \% \\
18.73 \%\end{array}$ & $\begin{array}{l}35.37 \% \\
53.86 \% \\
10.77 \%\end{array}$ & $\begin{array}{l}28.61 \% \\
57.62 \% \\
13.77 \%\end{array}$ \\
\hline $\begin{array}{l}3^{\text {rd }} \text { class } \\
\text { exact repetition: } \\
\text { expansion: } \\
\text { paraphrase: }\end{array}$ & $\begin{array}{l}17.35 \% \\
51.43 \% \\
31.22 \% \\
\end{array}$ & $\begin{array}{l}16.79 \% \\
59.21 \% \\
24.09 \% \\
\end{array}$ & $\begin{array}{l}31.76 \% \\
47.93 \% \\
20.31 \% \\
\end{array}$ & $\begin{array}{l}27.18 \% \\
47.29 \% \\
25.53 \% \\
\end{array}$ \\
\hline $\begin{array}{l}4^{\text {th }} \text { class } \\
\text { exact repetition: } \\
\text { expansion: } \\
\text { paraphrase: }\end{array}$ & $\begin{array}{l}22.57 \% \\
49.52 \% \\
27.91 \%\end{array}$ & $\begin{array}{l}18.94 \% \\
62.37 \% \\
18.69 \%\end{array}$ & $\begin{array}{l}28.59 \% \\
60.17 \% \\
11.24 \%\end{array}$ & $\begin{array}{l}27.53 \% \\
46.86 \% \\
25.61 \% \\
\end{array}$ \\
\hline $\begin{array}{l}\text { Average } \\
\text { exact repetition: } \\
\text { expansion: } \\
\text { paraphrase: }\end{array}$ & $\begin{array}{l}27.36 \% \\
58.29 \% \\
14.35 \%\end{array}$ & $\begin{array}{l}20.45 \% \\
61.42 \% \\
18.16 \%\end{array}$ & $\begin{array}{l}29.58 \% \\
57.57 \% \\
12.85 \%\end{array}$ & $\begin{array}{l}25.71 \% \\
55.62 \% \\
18.78 \% \\
\end{array}$ \\
\hline
\end{tabular}

As table 6 showed, the CET on the whole used more self-repetition utterances than the AET did. With respect to comprehensible input, the more self-repetition implied the better facilitative teaching. However, the data in table 7 showed that both the AET and the CET used lower percentages of paraphrase than exact-repetition in their teachings. Table 7 also showed that they both used expansion most to repeat their utterances, but the percentages of expansion used by the CET were a bit lower than those by the AET. According to Urano (1999), expansion and paraphrase would provide a better linguistic input than that of exact-repetition because expansion and paraphrase can create a richer and more natural learning environment. When teachers say the thing in several different ways, it gives students more than one chance to figure out what has been said and get some clues to alternative expressions for one thing as well. Instead, when teachers say the thing in just one way, it reflects the unnaturalness. The data indicated that both the AET and the CET need to improve their paraphrasing skills when repeat the utterances in order to provide comprehensible input to the learners. Also, the data indicated that the CET was a bit less flexible than AET in terms of language variety, which also highlighted the relatively insufficient flexibility on target language use of the CET compared to the AET.

\section{IMPLICATIONS FOR ACADEMIC ENGLISH WRITING TEACHING}

The empirical study showed that CETs indeed used less English in EFL classrooms, but they did not lag far behind in terms of linguistic complexity and linguistic variety. In other words, AETs may offer more but not necessarily better target language input in which quantity would be the major consideration based on the present study. Furthermore, the study indicated that relatively less proficient English could be the major reason for different teacher talk even though this proficiency was assumed by teachers, good understanding of teaching goals is also possible explanations for language use in the classroom. Also, in order to provide learners with more authentic input, both AETs and CETs should improve their paraphrasing skills. Paraphrasing is a crucial skill in academic English writing, and teachers can set good examples of effective paraphrasing to students through their talk in classes. Finally, for CETs, they need to maximize the use of English in classroom because use of L1 can reduce students' opportunities to think in English and use it in the classroom. After all, there are not many chances for learners to use English in their daily life outside the classroom. Input quantity may enlarge the chance to quality exposure and comprehensible input.

Last, the study seems to justify hiring AETs to create a better English learning environment in terms of more exposure to the target language, but it does not discourage the teaching of CETs. In EFL classrooms, apart from teacher talk, other components in teaching such as methods, practices, knowledge and attitude are all very important. As Maum (2002) concluded qualified and trained non-native speaking teachers can contribute in meaningful ways to the English education field with their own experiences as English learners and their training and teaching experiences. Thus, hiring 
native English speakers can maximize learning opportunities for authentic communication.

\section{LiMitATIONS OF This STUdy AND SUGGESTIONS FOR FUTURE RESEARCH}

The study only examined two teachers' language use in EFL classrooms, so findings have limitations. Due to the small number of cases being representative all AETs and CETs in EFL classrooms, findings are difficult to generalize to other contexts. Therefore, several suggestions for future research are made: 1). other methods such as questionnaires and interviews can be used to enhance validity; 2). enlarge the number of teachers examined; 3 ). carry out comparative studies in different contexts related to different learners' English proficiency.

\section{REFERENCES}

[1] Breidbach, S., Daniela, E. and Andrea Y. (2011). Language Awareness in Teacher Education: Cultural-Political and Social-Educational Perspectives, Peter Lang, Frankfurt am Main.

[2] Chadwick, T. (2012). Language Awareness in Teaching: A Toolkit for Content and Language Teachers. Cambridge University Press, Cambridge.

[3] Chaudron, C. (1998). Second Language Classrooms: Research on Teaching and Learning, Cambridge University Press, Cambridge.

[4] Cullen, R. (1998) "Teacher talk and the classroom context”, English Language Teaching Journal, Vol.52, 179-187.

[5] Duff, P. \& Polio, C. (1990). "How much foreign language is there in the foreign language classroom"? Modern Language Journal, Vol. 74, 154-166.

[6] Ellis, R. (1985b). Understanding Second Language Acquisition, Oxford University Press, Oxford.

[7] Ellis, R. (2003). Task-based Language Teaching and Learning. Oxford: Oxford University Press.

[8] Hadley, A. (2001). Teaching Language in Context ( $3^{\text {rd }}$ ed.), Heinle \& Heinle, Boston.

[9] Hale, C. (2011). "Breaking with the IRF and EPA: Facilitating student initiated talk", in A. Stewart (ed.), JALT2010 Conference Proceedings. Tokyo: JALT.

[10] Hall, G. (2011). Exploring English Language Teaching: Language in Action, Routledge, Abingdon.

[11] Kiasi, M.A. and Hemmati, F. (2014). "The importance of 'teacher talk' in teaching EFL writing”, Porta Linguarum, Vol. 22, 95-108.

[12] Krashen, S. (2004). “Applying the Comprehension Hypothesis: Some Suggestions”, Presented at $13^{\text {th }}$ International Symposium and Book Fair on Language Teaching (English Teachers Association of the Republic of China), Taipei, Taiwan.

[13] Levine, G. (2003). "Student and instructor beliefs and attitudes about target language use, first language use, and anxiety: report of a questionnaire study", Modern Language Journal, Vol.87, 343-364.

[14] Nakaruma, I. (2008). "Understanding how teacher and student talk with each other: an exploration of how "repair" displays the co-management of talk-in-interaction", Language Teaching Research, Vol.12, Issue 2: 265-283.

[15] Tang, J. (2002). "Using L1 in the English Classroom”, English Teaching Forum, Vol. 40, 36-43.

[16] Urano, K. (1999). "Teacher input and interaction: native and non-native speaker teachers in ESL classrooms", Bulletin of the Chubu English Language Education Society, Vol.28 265-272.

[17] Warford, M. K. (2007). "L1 vs. L2 in the foreign language classroom: New findings", in NECTFL Review, Vol.60, 50-67.

Julan Wang was born in Jian, Jiangxi Province, China in 1976. She received her master degree in applied linguistic from Xiamen University, China in 2003.

She is currently a senior lecturer in SHU-UTS SILC Business School, Shanghai University, Shanghai, China. Her research interests include English as a foreign language teaching and learning and intercultural communication.

Ms. Wang is a member of Chinese Association of Foreign Language Teachers. 